\title{
Evaluation of Some Biochemical Responses in Resistance of Fifteen Bread Wheat (Triticum aestivum L.) Genotypes to Wheat streak mosaic virus
}

\author{
Seyyed Rasoul Sahhafi (Corresponding author), Fatemeh Bagheri \& Mohammad Taghi Assad \\ Department of Crop Production and Plant Breeding \\ College of Agriculture, Shiraz University, Shiraz, Iran \\ Tel: 98-913-355-7187 E-mail: s.r_sahhafi@yahoo.com \\ Mahmoud Masumi \\ Plant Virology Research Center \\ College of Agriculture, Shiraz University, Shiraz, Iran \\ Majid Talebi \\ Department of Agricultural Biotechnology \\ College of Agriculture, Isfahan University of Technology, Isfahan, Iran
}

Received: December 6, 2011

Accepted: December 19, $2011 \quad$ Online Published: April 1, 2012

doi:10.5539/jas.v4n5p75

URL: http://dx.doi.org/10.5539/jas.v4n5p75

\begin{abstract}
Two greenhouse experiments were conducted in 2008-2010 at College of Agriculture, Shiraz University, Iran to evaluate the effectiveness of changes in protein content, peroxidase activity, phenolic compounds, free amino acids content and proline in response to wheat streak mosaic virus (WSMV) infection, in screening resistant bread wheat (Triticum aestivum L.) genotypes. Fifteen wheat genotypes consisting of WSMV tolerant, intermediate and susceptible genotypes were grown in two randomized complete designs with three replications. The experiments only differed with respect to their inoculation (either infected or non-infected). The results indicated that viral infection increased the total protein and peroxidase activity of leaves in tolerant genotypes but viral infection decreased them in susceptible genotypes. Phenolic compounds increased in all infected genotypes but these increases are the highest in tolerant genotypes as compared to intermediate and susceptible ones. Viral infection reduced free amino acids in genotypes in general. The changes in proline content did not show a typical trend in tolerant, intermediate or susceptible genotypes. The analysis of variance indicated that the linear regression of leaf damage rating on the changes in total protein, peroxidase activity and phenols in the leaf was significant but the linear regression of leaf damage rating on the changes in free amino acids and proline in the leaf was not significant. Our results demonstrate the changes in total protein, peroxidase activity and phenolic compounds in a genotype could be used as suitable biochemical markers for assessing the WSMV tolerant wheat plants when grown under infected condition.
\end{abstract}

Keywords: WSMV, Resistance, Biochemical responses, Regression

\section{Introduction}

Wheat streak mosaic virus is one of the most harmful viruses of bread wheat, Triticum aestivum L., in the United States, the Canadian Great Plains, Iran and other major wheat producing regions (Bockus et al., 2001; Masumi et al., 1999). Host plant resistance is a highly desirable control strategy when dealing with WSMV disease. Evaluation of the degree of resistance and tolerance in existing cultivars would be useful to plant breeders to provide potential sources of resistance and tolerance. Masumi et al. (1999) collected and preserved samples of 91 wheat species and cultivars from whole of Iran and found out 11 of 91 genotypes those were relatively resistant to WSMV. Adl-Cross was subsequently introduced by Yassaie et al. (2002) as completely resistant to WSMV in comparison with those genotypes. The resistant gene in Adl-Cross is apparently controlled by a dominant gene (Hassani and Assad, 2004). 
Plant organisms possess a complex set of defense mechanisms for preventing unfavorable interactions with other living organisms or for reducing negative effects of such interactions (Talarczk and Hennig, 2001). When a plant recognizes an invading pathogen, active defense mechanisms are induced which can include a hypersensitive response, accumulation of antimicrobial phytoalexins, synthesis of hydrolyses and pathogenesis-related proteins, reinforcement of cell walls through callose deposition and lignification, and activation of defense-related genes (Hammond-Kosack and Jones, 1996). Defense mechanisms in a susceptible plant are induced more slowly than those of a resistant plant, and the time required to induce a variety of defense responses appears to be a key factor resulting in a resistant phenotype (Yang et al., 1997).

Pathogenesis-related proteins (PRs) have been defined as plant proteins that are induced in pathological or related situations (Van Loon et al., 1994). Constitutive expression of individual PRs in transgenic plants can lead to reduced pathogen growth and symptom expression, consistent with a role of PRs in the expression of acquired resistance (Ryals et al., 1994).

There is an increasing evidence that, in some cases, constitutively expressed genes encoding enzymes associated with normal plant metabolism also play critical roles in the induction of plant defenses against pathogens (Eckardt, 2003). Polyphenol oxidase and peroxidase, the enzymes involved in the oxidation of phenols to more toxic quinines, are known to increase in several infected plants (Bajaj et al., 1983). Peroxidases are involved in the oxidation of phenolic compounds in cell walls, polymerization of lignin and suberin, and in several other oxidation processes (Fossdal et al., 2001).

Phenolics are well-known antifungal, antibacterial and antiviral compounds occurring in plants (Sivaprakasan and Vidhyasekaran, 1993). According to Matern and Kneusal (1988), the first step of the defense mechanism in plants involves a rapid accumulation of phenols at the infection site, which restricts or slows the growth of the pathogen. Phenols are found in plants in the forms of glycosides, which act as mobilized defense system can be translocated by plants and enzymatically converted into defensive substance at the site of attack (Shahida et al., 2001).

Plant amino acid biosynthetic pathways lead to the production of various secondary products that function as growth regulators, in defense against pathogens and other environmental stresses, and as structural components (Kutchan, 1995).

Rapid accumulation of free proline is also a typical response to stress and when plants are exposed to stress, many plants accumulate high amounts of proline, in some cases several times the sum of all other amino acids (Mansour et al., 2000). The role of proline in protection of cell membranes against stress injury has been discussed by Mansour et al. (1998).

This present work was conducted to evaluate the effectiveness of changes in protein content, peroxidase activity, phenol compounds, free amino acids content and proline content in response to wheat streak mosaic virus infection, in screening resistant bread wheat (Triticum aestivum L.) genotypes.

\section{Materials and Methods}

Two experiments were conducted in 2008-2010 at the greenhouse of College of Agriculture, Shiraz University, at Badjgah (Iran). Fifteen hexaploid wheat genotypes obtained from Fars Agricultural and Natural Resource Research Center, Zarghan, (Iran) were used in both experiments. According to the ranking proposed by the Masumi et al. (1999), five WSMV tolerant genotypes (M-73-6, Adl-Cross, Chamran, M-75-6 and C-73-20), five intermediate (Niknejad, Falat, Sardari, Karoon dar kavir and Alvand) and five WSMV susceptible genotypes (Darab, Roshan, Shiraz, Sabalan and Marvdasht) were used. Genotypes were planted in two pot experiments using randomized complete designs each with three replications. The two experiments differed with respect to their inoculation (either infected or non-infected): Seedlings in first experiment were inoculated with WSMV ten days after planting, while seedlings in second experiment served as control. Plants were grown in growth chamber at $25 / 20^{\circ} \mathrm{C}$ day/night. The WSMV isolate used in this study was the same as that used by Yassaie et al. (2002) in screening experiments. Wheat genotypes were mechanically inoculated by spraying the plants with a mixture of Carborundum and diluted sap from WSMV infected plants. Plants were inoculated at two to three-leaf stages.

Eight days after inoculation, leaves of each seedling in the two experiments were harvested, weighed and frozen at $-70^{\circ} \mathrm{C}$ for later assessment of protein, peroxidase activity, phenolic compound, free amino acids and proline. The leaf tissue (about $0.5 \mathrm{~g}$ fresh weights) was homogenized using mortar and pestle in $2 \mathrm{ml}$ of extraction buffer (pH 8.0) containing $1 \mathrm{ml}$ of $50 \mathrm{mM}$ Tris- $\mathrm{HCl}, \mathrm{pH} 8.0$ at $25^{\circ} \mathrm{C}, 10 \mathrm{mM} \mathrm{MgCl} 2,2.5 \mathrm{mM}$ dithioerythritol and $10 \%$ glycerol $(\mathrm{v} / \mathrm{v})$. The homogenate was centrifuged in a refrigerated centrifuge at $1000 \mathrm{~g}$ for 20 minutes at $4^{\circ} \mathrm{C}$. The resulting supernatant was used for analysis of protein, peroxidase activity and free amino acids assay. 
Total Protein content was determined spectrophotometrically at $595 \mathrm{~nm}$, using comassie blue $\mathrm{G} 250$ as a protein binding dye (Bradford, 1976). Bovine serum albumin (BSA) was used as a protein standard.

Peroxidase activity was determined as described by Poll et al. (1994). Enzyme extracts ( $50 \mu \mathrm{l})$ were mixed with 5 $\mathrm{ml}$ extraction buffer $\left(100 \mathrm{mM} \mathrm{KH}_{2} \mathrm{PO}_{4} / \mathrm{K}_{2} \mathrm{HPO}_{4} \mathrm{pH}\right.$ 7), containing $20 \mathrm{mM}$ Guaiacol and $10 \mathrm{mM} \mathrm{H}_{2} \mathrm{O}_{2}$. Peroxidase activities were determined spectrophotometrically at $436 \mathrm{~nm}$.

Extraction and determination of free phenolics were carried out according to Campbell and Ellis (1992) and Julkunen-Tiitto (1985), respectively. A quantity of $50 \mathrm{~g}$ of each powdered leaf material was extracted and soaked in 2 volumes of $50 \%$ of methanol at $80^{\circ} \mathrm{C}$ for $1.5 \mathrm{~h}$. The extracted material was centrifuged, the supernatant was taken and methanol was evaporated under suction. The supernatant was used for measuring phenolic content. The phenolic content was determined using the Folin-Ciocalteau reagent and a spectrophotometer at $725 \mathrm{~nm}$.

Total free amino acids were determined using the method described by Yemm and Cocking (1955) and measured by a spectrophotometer at $520 \mathrm{~nm}$. Total free amino acids were expressed as milligrams of glycine per gram of fresh weight.

Extraction and determination of proline was performed according to the method of Bates et al. (1973). Leaf samples $(1 \mathrm{~g})$ were extracted with 3\% sulphosalicylic acid. Extracts $(2 \mathrm{ml})$ were held for $1 \mathrm{~h}$ in boiling water by adding $2 \mathrm{ml}$ ninhydrin and $2 \mathrm{ml}$ glacial acetic acid, after which cold toluene $(4 \mathrm{ml})$ was added. Proline content was measured by a spectrophotometer at $520 \mathrm{~nm}$.

WSMV damage symptoms was assessed using the damage rating determined by Masumi et al. (1999) and based on symptoms observed on lower leaves and systemic spread of the virus to upper leaves 9 to 10 weeks after inoculation. For symptomatology, the lower four to five leaves were rated on a scale of 0 to 7 . Seedlings showing chlorotic spots without streaking and leaf rolling were considered tolerant while those developed some mosaic but very little yellowing and stunting were grouped as intermediate. Other genotypes exhibited extremely mosaics and severe yellowing, stunting and leaf rolling were counted as susceptible.

Statistical analysis were carried out with the program SAS (SAS Institute, Carry, NC, U.S.A., Version 6.06). Differences among mean protein content, peroxidase activity, phenolic compounds, free amino acids content and proline changes were analyzed using $t$ test. The regression of damage rating on each five Biochemical responses under non-infected and infected conditions was also determined.

\section{Results and Discussion}

\subsection{Symptom Severity of Wheat Genotypes}

The range and mean of WSMV damage rating of all genotypes are showed in Table 1. Symptoms of WSMV were not observed at any time in non-infected controls. Typical yellowing and streak mosaic symptoms had developed in inoculated plants by approximately 2 weeks after inoculation, while mild to severe symptoms were observed as the season progressed.

\subsection{Leaf Protein Content}

The leaf protein content of genotypes in non-infected and infected conditions is given in Table 1. Results indicate that total protein content apparently discriminated between WSMV tolerant, intermediate and susceptible genotypes in both conditions. Susceptible genotypes, on the average showed the lowest protein content than intermediate and tolerant genotypes at non-infected condition. The highest protein content at non-infected condition was belonged to tolerant genotypes: Chamran and M-73-6 while, susceptible genotypes: Marvdasht and Shiraz showed the lowest amount. However, infection increased total protein in resistant and intermediate genotypes, significantly. On the other hand, susceptible genotypes showed a significant reduction of leaf protein content. The tolerant genotypes: Chamran, Adl-Cross and M-73-6 had the highest amount of protein content at infected condition while susceptible genotypes: Marvdash, Shiraz and Roshan had the lowest amount. This is in agreement with the results obtained by others (Hosseini Nezhad et al., 2008; Zinati, 2009). The linear relationship between leaf damage rating on the changes in leaf protein content was significant (Table 2). The pathogenesis-related proteins (PRs), defined as proteins coded for by the host plant and are also induced systemically, were associated with the development of systemic acquired resistance against further infection by fungi, bacteria and viruses. Induction of PRs has been found in many plant species belonging to various families, suggestive of a general role for these proteins in adaptation to biotic stress conditions (VanLoon and Van Strien, 1999).

Accumulation of the pathogenesis-related proteins represents the major quantitative change in protein composition that occurs in non-inoculated plant parts that, upon challenge, exhibit acquired resistance (Van Loon, 1997). In addition to pathogenesis-related proteins, small peptides with antimicrobial activity, such as thionins, defensins and lipid transfer proteins, also accumulate in infected plants and are probably components of 
the induced defense system (Fritig et al., 1998). So the changes in total protein contents can provide the guidelines in screening of high tolerant plants to WSMV.

\subsection{Peroxidase Activity}

Peroxidase activities of genotypes in non-stress and stress conditions are given in Table 1 . The variation in peroxidase activities between tolerant, intermediate and susceptible genotypes in both conditions was similar to those of leaf protein content. The highest enzyme activities were observed in Adl-Cross, Chamran and M-73-6, while Niknejad, Karoon dar kavir and Roshan produced the lowest amount at non-infected condition. Chamran, Adl-Cross and M-73-6 had the highest POD activity at infected condition. while Marvdash, Shiraz and Sabalan had the lowest amount. The peroxidase activity of WSMV tolerant genotypes were, on the average, higher than those of intermediate and susceptible ones in all conditions, indicating that it was an effective technique in screening resistant genotypes. Other investigators (Hosseini Nezhad et al., 2008; Zinati, 2009) also reported that WSMV resistant cultivars had higher peroxidase activity as compared to susceptible ones. The regressions of leaf damage rating on the changes in peroxidase activity were significant (Table 2). Galletti and Burzi (2003) found out that in sugar beet (Beta vulgaris) the resistant cultivars to Cercospora beticola (a sugar beet necrotrophic pathogen) always showed peroxidase activity significantly higher than the susceptible ones. Peroxidase is important in defense mechanism against pathogens, through its role in the oxidation of phenolic compounds to quinines, causing increasing antimicrobial activity. It is showed that peroxidase may be directly involved in stopping pathogen development (Shimizu et al., 2006); accelerating the cellular death of cells close to the infection site, preventing the advance of infection and/or by generating a toxic environment, which will inhibit the growth of the pathogen inside the cells (Bi and Felton, 1995). Peroxidase enzyme probably affects synthesis of compounds effective in conferring resistance. This indicates that the changes in peroxidase activity might be a good trait for selecting resistant wheat genotypes to WSMV.

\subsection{Free Phenolic Compounds Content}

The mean phenolic compounds for non-infected and infected conditions are showed in Table 1. Genotypes did not differ significantly in respect to free phenolic compounds under non-infected conditions, however the differences were significant under stress conditions and this emphasized the different responses of genotypes to infected conditions. There was significant increase in phenolic compounds concentration in all genotypes under stress condition but these increases are the highest in tolerant genotypes as compared to intermediate and susceptible genotypes. The tolerant genotypes: Chamran, Adl-Cross and M-73-6 produced the highest phenolic compounds when compared with other genotypes. Hosseini Nezhad et al. (2008) reported that synthesis of phenolic compounds was higher in Adl-Cross (tolerant genotypes) as compared with that in Marvdasht (susceptible one) in infected conditions. Zinati (2009) emphasized on these results and also demonstrated that temperature above $32^{\circ} \mathrm{C}$ decreased phenolic compounds in Adl-Cross. The analysis of variance indicated that the linear regression of leaf damage rating on the changes in free phenol compounds content in the leaf was significant (Table 2). Phenolic compounds were suggested to be one component of many others that affect the resistance of cereals to Fusarium wilt and principally concentrated in the outer layers of wheat where they can readily contribute to disease inhibition (Mandavia et al., 1997). Kofalvi and Nassuth (1995) also reported that WSMV influenced phenylpropanoid metabolism and the accumulation of phenolics as well as lignin in wheat. These results emphasize that phenolic compounds concentration could be adopted as selective criteria in preliminary stages of selection for tolerance to WSMV.

\subsection{Free Amino Acid Content}

As shown in Table 1 viral infection reduced free amino acids in majority of genotypes significantly eight days from inoculation. Also, the content of free amino acids increased in some genotypes including Niknejad, Karoon dar kavair, Alvand, Darab and Sabalan but significant increase in free amino acids was only recorded in Alvand and Darab. As given in Table 2 the analysis of variance showed that the regression of leaf damage rating on the changes in the free amino acids in the leaf of wheat genotypes was not significant. Anwar (1986) also reported reduction of amino acids content of the infected tissue of sorghum and maize. Mogle and Mayee (1981) reported reduction of amino acids content in pearl millets. The decrease of free amino acids content may either be due to the utilization by the pathogen enzymatic degradation or have been utilized by the host plant for the defense mechanism (Bashhalah et al., 1984). Dasgupta et al. (2003) reported that many viruses need cysteine protease activity to process their own poly-proteins for their replication and propagation. The decrease in the above-mentioned free amino acids content might be due to the synthesis of this enzyme, the production of other protein structures and also replication of virus. From these findings it can be suggested that virus materials produced by the amino acids might be a reason for reduction in free amino acids content of leaves. These results may indicate that free amino acids content could not be adopted as selective trait in preliminary stages of selection for tolerance to WSMV. 


\subsection{Proline Content}

Proline contents of leaves are presented in Table 1. The results showed that proline contents of leaves increased in the majority of genotypes except in C-73-20, Niknejad and Falat. However, there was not variation between tolerant, intermediate and susceptible genotypes in regard to proline concentration under non-infected and infected conditions (Table 1). The analysis of variance showed that the linear relationship between leaf damage rating on the changes in leaf proline content was not significant as shown in Table 2. However, our findings disagree with the report by Hosseini Nezhad et al. (2008) who showed that the changes of proline content in WSMV tolerant and susceptible cultivars were not significant in both non-infected and infected conditions. Proline accumulation is a plant resistance mechanism to various stress factors, such as drought, salinity, low temperature and high temperature. In tolerant genotypes, a high accumulation of proline and little anomaly on chloroplast ultra-structure were observed (Cárdenas-Avila et al., 2006). Our results showed that proline accumulate in higher contents in infected conditions as compared to non-infected condition in all genotypes, therefore the accumulation of proline is not considered an indicator for selection of tolerant wheat plants to WSMV.

\section{Conclusion}

Considering the results obtained it may be concluded that the changes in total protein content, peroxidase activity and phenolic compounds in a genotype are associated well with resistance to wheat streak mosaic virus in wheat genotypes. These biochemical responses could be used as suitable biochemical markers for assessing the WSMV tolerant wheat plants when grown under infected condition. For more reliability of results use of more genotypes are recommended in the future studies.

\section{Acknowledgements}

We thank Fars Agricultural and Natural Resource Research Center, Zarghan, Iran, for providing the wheat seeds. We greatly appreciate Dr. Hooman Razi and Dr. Abbas Alemzade for their assistance in conducting the experiments.

\section{References}

Anwar, M. N. (1986). Some chemical parameters of biodeterioration of host plant sorghum and maize due to infection by Peronosclorospora sorghi. Phytopathology, 71, 12-19.

Bajaj, K.L., Arora, Y. K., \& Mahajan, R. (1983). Biochemical differences in tomato cultivars resistant and susceptible to Meloidogyne incognita. Revue. Nematology, 6 (1), 143-154.

Bashalah, M.O., Sulaiman, A. A. A., \& Mohammad, S. (1984). Metabolic changes in the leaves of Solanum melongina affected with Alternaria tenuissima. Indian Phytopathology, 37, 46-51.

Bates, A.S., Waldren, R. P., \& Teare, I. D. (1973). Rapid determination of free proline for water-stress studies. Plant and soil, 39, 205-207. http://dx.doi.org/10.1007/BF00018060

Bi, J. L., \& Felton, G. W. (1995). Foliar oxidative stress and insect herbivory: primary compounds, secondary metabolites and reactive oxygen species as components of induced resistance. Journal of Chemical Ecology, 21, 1511-1530. http://dx.doi.org/10.1007/BF02035149

Bockus, W. W., Appel, J. A., Bowden, R. L., Fritz, A. K., Gill, B. S., Martin, T. J., Sears, R. G., Seifers, D. L., Brown-Guedira, G. L., \& Eversmeyer, M. G. (2001). Success stories: Breeding for wheat disease resistance in Kansas. Plant Disease, 85, 453-461. http://dx.doi.org/10.1094/PDIS.2001.85.5.453.

Bradford, M. M. (1976). A rapid and sensitive method for the quantification of microgram quantities of protein utilizing the principles of protein-dye binding. Analytical Biochemistry, 72, 247-254. http://dx.doi.org/10.1016/0003-2697(76)90527-3

Campbell, M. M., \& Ellis, B. E. (1992). Fungal elicitor- mediated responses in pine cell cultures. Planta, 186: 409- 417. http://dx.doi.org/10.1007/BF00195322

Cárdenas-Avila, M. L., Verde-Star, J., Maiti, R. K., Foroughbakhch-P., R., Gámez-González, H., Martínez-Lozano, S., Núñez-González, M. A., García Díaz, G., Hernández-Piñero, J. L., \& Morales-Vallarta, M. R. (2006). Variability in accumulation of free proline on in vitro calli of four bean (Phaseolus vulgaris L.) varieties exposed to salinity and induced moisture stress. International Journal of Experimental Botany, 75, 103-108.

Dasgupta, I., Malathi, V. G., \& Mukherjee, S. K. (2003). Genetic engineering for virus resistance. Current Science, 84 (3), 341-354.

Eckardt, N. A. (2003). Viral defense and counter defense: A role for adenosine kinase in innate defense and RNA silencing. Plant Cell, 15, 2758-2761. http://dx.doi.org/10.1105/tpc.151211 
Fossdal, C. G., Sharma, P., \& Lonneborg, A. (2001). Isolation of the first putative peroxidase cDNA from a conifer and local and systemic accumulation of related proteins upon pathogen infection. Plant Molecular Biology, 47, 423-435. http://dx.doi.org/10.1023/A:1011615328684.

Fritig, B., Heitz, T., \& Legrand, M. (1998). Antimicrobial proteins in induced plant defense. Current Opinion Immunology, 10, 16-22. http://dx.doi.org/10.1016/S0952-7915(98)80025-3

Galletti, S., \& Burzi, P. L. (2003). Variation of peroxidase activity in sugar beet leaves infected with Cercospora beticola sacc. Journal of Plant Patholoy, 85 (4, Special issue), 275- 320.

Hammond-Kosack, K. E., \& Jones, J. D. G. (1996). Resistance gene dependent plant defense response. Plant Cell, 8, 1773-1791.

Hassani, F., \& Assad, M. T. (2004). Inheritance and allelism of wheat streak mosaic virus resistance in two Iranian wheat lines. Euphytica, 140, 213-216. http://dx.doi.org/10.1007/s10681-004-3284-y

Hosseini Nezhad, S. M., Assad, M. T., \& Masumi, M. (2008). Evaluation of some biochemical factors in resistance to Wheat Streak Mosaic Virus. The Scientific Journal of Agriculture, 31, 39-54.

Julkunen- Tiitto, R. (1985). Phenolic constituents in the leaves of northern willows: methods for the analysis of certain phenolics. Journal of Agricultural and Food Chemistry, 33, 213-217. http://dx.doi.org/10.1021/jf00062a013

Kovalvi, S. A., \& Nassuth, A. (1995). Influence of Wheat Streak Mosaic Virus infection on phenylpropanoid metabolism and the accumulation of phenolics and Lignin in Wheat. Physiological and Molecular Plant Pathology, 47, 365-377. http://dx.doi.org/10.1006/pmpp.1995.1065

Kutchan, T. M. (1995). Alkaloid biosynthesis, the basis for metabolic engineering of medicinal plants. Plant Cell., 7, 1059-1070.

Mandavia, M. K., Patel, C. M., Maravia, G. V., \& Aramesw-aran, M. P. (1997). Role of phenolic compounds in resistance to fusarium wilt in chickpea. Indian Journal of Agricultural Biochemistry, 10 (1\&2), 11-13.

Mansour, M. M. F. (1998). Protection of plasma membrane of anion epidermal cells by glycinbetaine and praline against $\mathrm{NaCl}$ stress. Plant Physiology, 36, 767-772.

Mansour, M. M. F. (2000). Nitrogen containing compounds and adaptation of plants to salinity stress. Biology Plantarum, 43, 491-500. http://dx.doi.org/10.1023/A:1002873531707

Masumi, M., Kamran, R., Shiravani, A., \& Izadpanah, K. (1999). Reaction of wheat genotypes to wheat streak mosaic virus in Iran. Iranian Journal of Plant Pathology, 35, 9-18.

Matern, U., \& Kneusal, R. E. (1988). Phenolic compounds in plant disease resistance. Phytopathogy, 16, 153-170.

Mogle, I. R., \& Mayee, C. D. (1981). Comparative changes in reducing sugar, starch and free amino acids accompanying downy mildew infection in resistant, moderately resistant and susceptible leaves of Pearl millet. Indian Journal of Mycology and Pathology, 2, 61-65.

Polle, A., Otter, T., \& Seifert, F. (1994). Apoplastic peroxidases and lignification in needle of Picea abies. Plant Physiolpgy, 106, 53-60.

Ryals, J., Uknes, S., \& Ward, E. (1994). Systemic acquired resistance. Plant Physiology, 104, 1109-1112.

Shahida, S. P., Qaisrani, T. M., Bhutta, S., Riffat, P., \& Naqvi, S. H. M. (2001). HPLC analysis of cotton phenols and their contribution in bollworm resistance. OnLine Journal of Biological Sciences, 1 (7), 587-590.

Shimizu, N., Hosogi, N., Hyon, G.S., Jiang, S., Inoue, K., \& Park, P. (2006). Reactive oxygen species (ROS) generation and ROS induced lipid peroxidation are associated with plasma membrane modifications in host cells in response to $A K$-toxin 1 from Alternaria alternate Japanese pear pathotype. Journal of General Plant Pathology, 72, 6-15. http://dx.doi.org/10.1007/s10327-005-0245-9

Sivaprakasan K., \& Vidhyasekaran, P. (1993). Phenylalanine ammonia lyase gene for crop disease management. In: Vidhyasekaran P, ed. Genetic Engineering, Molecular Biology and Tissue Culture for Crop Pest and Disease Management. Delhi, India. pp: 113-122.

Talarczyk, A., \& Hennig, J. (2001). Early defence responses in plants infected with pathogenic organism. Cellular \& Molecular Biology Letters, 6, 955-970.

Van Loon, L. C., Pierpoint, W. S., Boller, Th., \& Conejero, V. (1994). Recommendations for naming plant pathogenesis protein. Plant Molecular Biology Reporter, 12, 245-264. http://dx.doi.org/10.1007/BF02668748 
Van Loon, L. C. (1997). Induced resistance in plants and role of pathogenesis-related proteins. European Journal of Plant Pathology, 103, 753-765. http://dx.doi.org/10.1023/A:1008638109140

Van Loon, L. C., \& VanStrien, E. A. (1999). The families of pathogenesis-related proteins, their activities, and comparative analysis of PR-1 type proteins. Physiological and Molecular Plant Pathology, 55, 85-97. http://dx.doi.org/10.1006/pmpp.1999.0213

Yang, Y., Shah, J., \& Klessig, D. F. (1997). Signal perception andtransduction in plant defense responses. Genes \& Development, 11, 1621-1639. http://dx.doi.org/10.1101/gad.11.13.1621

Yassaie, M., Masumi, M., Amin, H., \& Izadpanah, K. (2002). Evaluation of wheat streak mosaic virus response in commercial and native wheat ancestors. In: Proceedings of the $15^{\text {th }}$ Iranian Congress of Plant Pathology, 7-11 Sep., University of Razi, Kermanshah, Iran. pp: 32.

Yemm, E. W., \& Cocking, E. C. (1955). The determination of amino-acids with ninhydrin. Analyst, 80, 209-213. http://dx.doi.org/10.1039/an9558000209

Zinati, Z. (2009). The effect of temperature on biochemical changes in inoculation period in resistant and susceptible bread wheat genotypes to Wheat Streak Mosaic Virus. M.Sc. Thesis. Shiraz University, Shiraz, Iran.

Table 1. Range and mean of WSMV damage rating and mean of total protein ( $\mathrm{mg} \mathrm{g}^{-1}$ fresh weight), peroxidase activity ( $\mu \mathrm{g} \mathrm{g}^{-1}$ fresh weight), phenol content ( $\mu \mathrm{g} \mathrm{g}^{-1}$ fresh weight), free amino acids content ( $\mu \mathrm{g} \mathrm{g}^{-1}$ fresh weight) and proline content $\left(\mu \mathrm{g} \mathrm{g}^{-1}\right.$ fresh weight), of fifteen wheat genotypes under non-infected and infected conditions

\begin{tabular}{|c|c|c|c|c|c|c|c|}
\hline Genotypes & & $\begin{array}{c}\text { Range and mean } \\
\text { of WSMV damage } \\
\text { rating }\end{array}$ & $\begin{array}{c}\text { Total } \\
\text { protein } \\
\text { content }\end{array}$ & $\begin{array}{c}\text { Peroxidase } \\
\text { activity }\end{array}$ & $\begin{array}{l}\text { Phenol } \\
\text { content }\end{array}$ & $\begin{array}{c}\text { Amino acids } \\
\text { content }\end{array}$ & $\begin{array}{l}\text { Proline } \\
\text { conten }\end{array}$ \\
\hline \multirow[t]{2}{*}{ M-73-6 } & $\mathrm{N}$ & - & 0.763 & 1.613 & 3.046 & 0.099 & 2.656 \\
\hline & I & $0-1(0.78)$ & $1.036 * *$ & $2.320 * *$ & $4.743 * *$ & $0.088 *$ & $3.423 * *$ \\
\hline \multirow[t]{2}{*}{ Adl-Cross } & $\mathrm{N}$ & - & 0.706 & 1.633 & 3.656 & 0.085 & 2.116 \\
\hline & I & $0-2(0.94)$ & $1.050 * *$ & $2.780 * *$ & $5.363 * *$ & $0.067 * *$ & $2.833 * *$ \\
\hline \multirow[t]{2}{*}{ Chamran } & $\mathrm{N}$ & - & 0.913 & 1.633 & 3.596 & 0.117 & 2.413 \\
\hline & I & $0-2(1.08)$ & $1.143 * *$ & $2.466 *$ & $5.773 * *$ & $0.107 *$ & $2.990 * *$ \\
\hline \multirow[t]{2}{*}{ M-75-6 } & $\mathrm{N}$ & - & 0.553 & 1.493 & 3.146 & 0.070 & 2.506 \\
\hline & I & $0-2(1.33)$ & $0.686^{*}$ & $2.036^{* *}$ & $3.846 * *$ & $0.056 *$ & $3.323 * *$ \\
\hline \multirow[t]{2}{*}{ C- $73-20$} & $\mathrm{~N}$ & - & 0.683 & 1.483 & 2.980 & 0.089 & 3.26 \\
\hline & I & $0-3(1.36)$ & $0.800 *$ & $1.783 * *$ & $3.576 *$ & $0.073 *$ & $2.756 *$ \\
\hline \multirow[t]{2}{*}{ Niknejad } & $\mathrm{N}$ & - & 0.746 & 1.386 & 3.243 & 0.052 & 2.210 \\
\hline & I & $0-3(1.55)$ & $0.973 * *$ & $2.126^{*}$ & $4.596 * *$ & $0.058 \mathrm{~ns}$ & $1.713 *$ \\
\hline \multirow[t]{2}{*}{ Falat } & $\mathrm{N}$ & - & 0.646 & 1.500 & 3.183 & 0.074 & 2.496 \\
\hline & I & $0-3(1.8)$ & $0.786^{*}$ & $1.770 *$ & $4.276 * *$ & $0.054 * *$ & $2.413 \mathrm{~ns}$ \\
\hline \multirow[t]{2}{*}{ Sardari } & $\mathrm{N}$ & - & 0.566 & 1.590 & 2.776 & 0.088 & 2.130 \\
\hline & I & $2-6(2.58)$ & $0.550 \mathrm{~ns}$ & $1.446^{*}$ & $2.963 *$ & $0.063 * *$ & $2.353 \mathrm{~ns}$ \\
\hline \multirow[t]{2}{*}{ Karoon dar kavir } & $\mathrm{N}$ & - & 0.713 & 1.613 & 3.290 & 0.060 & 1.986 \\
\hline & I & $2-6(2.62)$ & $0.756 \mathrm{~ns}$ & $1.753 *$ & $4.186 * *$ & $0.069 \mathrm{~ns}$ & $2.643 * *$ \\
\hline \multirow[t]{2}{*}{ Alvand } & $\mathrm{N}$ & - & 0.543 & 1.416 & 3.123 & 0.062 & 2.786 \\
\hline & I & $2-7(2.77)$ & $0.640 *$ & $1.803 \mathrm{~ns}$ & $3.973 * *$ & $0.072 *$ & $3.700 * *$ \\
\hline \multirow[t]{2}{*}{ Darab } & $\mathrm{N}$ & - & 0.673 & 1.446 & 3.220 & 0.053 & 2.240 \\
\hline & I & $2-6(2.08)$ & $0.713 \mathrm{~ns}$ & $1.660 *$ & $3.886 * *$ & $0.073 *$ & $3.006 * *$ \\
\hline \multirow[t]{2}{*}{ Roshan } & $\mathrm{N}$ & - & 0.590 & 1.426 & 3.256 & 0.065 & 1.843 \\
\hline & I & $2-6(3.08)$ & $0.450 *$ & $1.256 \mathrm{~ns}$ & $3.506 \mathrm{~ns}$ & $0.044 * *$ & $2.700 * *$ \\
\hline \multirow[t]{2}{*}{ Shiraz } & $\mathrm{N}$ & - & 0.480 & 1.430 & 2.393 & 0.089 & 1.690 \\
\hline & I & $2-4(3.41)$ & $0.346^{*}$ & $1.210 * *$ & $2.606 \mathrm{~ns}$ & $0.066 *$ & $1.973 *$ \\
\hline \multirow[t]{2}{*}{ Sabalan } & $\mathrm{N}$ & - & 0.663 & 1.460 & 2.950 & 0.071 & 1.826 \\
\hline & I & $3-7(3.64)$ & $0.506 *$ & $1.386 \mathrm{~ns}$ & $3.260 \mathrm{~ns}$ & $0.073 \mathrm{~ns}$ & $2.160 *$ \\
\hline \multirow[t]{2}{*}{ Marvdasht } & $\mathrm{N}$ & - & 0.406 & 1.446 & 1.893 & 0.123 & 1.993 \\
\hline & $\mathrm{I}$ & 2- $4(3.74)$ & $0.253 *$ & $1.150 * *$ & $2.010 \mathrm{~ns}$ & $0.102 *$ & $2.670 * *$ \\
\hline
\end{tabular}

$\mathrm{N}=$ Non-infected, $\mathrm{I}=$ infected

**: Significant at 1\% levels of probability, *: Significant at 5\% levels of probability and ns: not significant in t test comparisons between the means of each wheat genotypes under non-stress and stress conditions. 
Table 2. The regression equations of leaf damage rating on five biochemical responses under non-infected and infected conditions

\begin{tabular}{lccc}
\hline Biochemical response & Regression equation & $\mathrm{R}^{2}(\mathrm{n})$ & $\mathrm{P}$ \\
\hline Total protein & $\mathrm{Y}=-3.062 \mathrm{x}+2.312$ & $0.74(15)$ & $<0.05$ \\
Peroxidase activity & $\mathrm{Y}=-3.615 \mathrm{x}+2.586$ & $0.77(15)$ & $<0.05$ \\
Phenolic compounds content & $\mathrm{Y}=-7.547 \mathrm{x}+3.692$ & $0.81(15)$ & $<0.05$ \\
Free amino acids content & - & - & $\mathrm{ns}$ \\
Proline content & - & - & $\mathrm{ns}$ \\
\hline
\end{tabular}

For calculating regression equations, $\mathrm{x}$ and $\mathrm{y}$ was determined using these formulas:

$\mathrm{x}=$ mean of WSMV damage ratings of each genotype

$y=1$ - (amount of biochemical responses in non-infected condition/amount of biochemical responses in infected condition)

$n s=$ Not significant 